\title{
Tilkoblings- og afkoblingsstrategier i dansk udenrigspolitik Udvikling og tendenser i de danske udenrigspolitiske doktriner
}

\author{
Rasmus Brun Pedersen \\ Lektor, Institut for Statskundskab, Aarhus Universitet og Institut for Erhvervskommunikation
}

Artiklen giver en analyse af de dominerende danske udenrigspolitiske doktriner fra 1914-2014 ved at undersøge hvordan Danmark har fortolket sine muligheder i sin udenrigspolitik, og hvordan dette er kommet til udtryk i vægtningen af forskellige tilkoblings- og afkoblingsstrategier i de udenrigspolitiske doktriner.

Traditionelt har studier af staters udenrigspolitiske doktriner været domineret af stormagtsstudier, mens der har været mindre fokus på udviklingen i småstaters udenrigspolitiske doktriner (Wivel 2014). Dette hænger bl.a. sammen med, at disse traditionelt har haft mere begrænsede muligheder for at tilrettelægge deres udenrigspolitiske strategier, herunder deres reaktionsmønstre og tilpasningsstrategier (Skidmore 1994; Snyder 1991, 20). Derfor har litteraturen om småstater og ikke mindst dansk udenrigspolitik oftest haft fokus på deres (reaktivt) tilpassende adfærd på de forskellige krav, som de er blevet mødt med $i$ et internationalt system domineret af globale eller regionale stormagter (jf. Pedersen \& Gram-Skjoldager 2015 for en oversigt over denne forskningsposition). Artiklen her sætter fokus på udviklingen i de doktriner, som har fungeret som overordnede kompas og retningsgivere for tilrettelæggelsen af den danske udenrigspolitik, og undersøger, hvordan man har fortolket sine muligheder i sin udenrigspolitik, og hvordan forskellige tilkoblings- og afkoblingsstrategier til det internationale samfund er kommet til udtryk i disse doktriner. Artiklen undersøger særligt relationen mellem to underlæggende ideologiske strøm- ninger, som traditionelt har udgjort kernen i den danske udenrigspolitiske tradition (eller strategiske kultur) (Branner 2000; jf. desuden Rasmussen 2005). Disse udgøres hhv. af determinismen og internationalismen. Førstnævnte relaterer typisk til de mere tilpasnings- orienterede elementer i dansk udenrigspolitik, oftest associeret med dansk afkobling til det internationale system. Internationalismen associeres som regel med et dansk engagement i det internationale samfund og dets institutioner og repræsenterer således dansk tilkobling til det internationale samfund. Der har længe været argumenteret for, at dansk udenrigspolitik kan forstås dualistisk i spændet mellem disse to modsatrettede, men ikke gensidigt udelukkende ideologiske strømninger (Branner 2000; Holbraad 1991; Villaume 1995). Artiklens analyse peger imidlertid på, at den traditionelle dualistiske fortolkning og dens begrebssætning af dansk udenrigspolitik synes udfordret i udviklingen efter Den Kolde Krigs afslutning, hvor tendensen i de officielle doktriner peger på formuleringen af en mere enstrenget internationalistisk udvikling, hvor de udenrigspolitiske doktriner bryder med Munchs og Hækkerups dualisme og kompartmentalisering af udenrigspolitikken. Dette rejser således nogle mere principielle overvejelser i forhold til, hvilke begrebssæt man skal anvende til at karakterisere dansk udenrigspolitik, hvor argumentet her er, at aktivisme og tilpasningsbegreberne ikke nødvendigvis hjælper os analytisk til at få greb om udviklingen i den nyere danske udenrigspolitik. Ligeledes problematiserer artiklen spørgsmålet om, hvordan brud og kontinuitet fortolkes i dansk udenrigspolitik gennem de forskellige typer af begrebssætninger. 


\section{En dansk udenrigspolitisk tradition og strategisk kultur?}

Den danske udenrigspolitiske litteratur har påpeget, at der kan identificeres en særlig dansk udenrigspolitisk identitet eller udenrigspolitisk tradition, der har guidet udførelsen af den danske udenrigspolitik (Rasmussen 2005; Branner 2013; Wivel 2014). Denne har ofte været associeret med landets småstatsstatus, hvilket har betydet, at den danske udenrigspolitik oftest har været guidet af forskellige tilpasningsresponser på den internationale udvikling (Holbraad 1991; Branner 2000; Petersen 1977). Denne identitet antages at være styret af to underlæggende og relaterede ideologiske strømninger, der har præget de danske beslutningstagere igennem det 20. århundrede. Disse har været struktureret omkring to overordnede og sameksisterende reaktionsmønstre, nemlig en deterministisk (eller tilpasningsorienteret) streng på den ene side og en internationalistisk eller normpolitisk tendens på den anden side (Holbraad 1991; Branner 2000). Dette har ledt til, at dansk udenrigspolitisk tradition eller den strategiske kultur i dansk udenrigspolitik oftest har været anset som dualistisk eller tostrenget samt været snævert koblet til den danske småstatsstatus i det internationale system.

\section{Determinisme i dansk udenrigspolitik}

Carsten Holbraad og Hans Branner har i hhv. 1991 og 2000 syntetiseret determinismen i denne forståelse og karakteriseret den ved en udpræget tilbageholdenhed over for omverdenen og et forsøg på at hindre trusler ved at tilpasse sig stormagtsinteresser. Dette beskrives også som udenrigspolitisk afkobling fra det internationale system (Holbraad 1991; Branner 2000). Den analytiske opmærksomhed omkring den defensive og reaktive tendens i den danske udenrigspolitik har dybe historiske rødder og kan spores tilbage til begyndelsen af det 20. århundrede, hvor den blev genstand for politisk debat under betegnelser som tyskerkursen eller tilpasningspolitikken. Vigtige eksponenter for den deterministiske tendens i den danske udenrigspolitik er Erik Scavenius og en anden radikal udenrigsminister, P. Munch (1929-1940), der havde en principfast tro på nødvendigheden af, at Danmark, pga. sin position som en lille udsat småstat, tilpassede sig til de internationale magtpolitiske realiteter (Bjøl 1996; 1970; Petersen 1999).

\section{Internationalisme $i$ dansk udenrigspolitik}

Den anden hovedstreng, som er blevet påpeget i 1900-tallets danske udenrigspolitik, er den internationalistiske, der historisk har været karakteriseret ved aktive bestræbelser på at skabe en mere fredelig og retfærdig verden baseret på internationale retsprincipper og fredelig kon- fliktløsning. Præmissen i denne udenrigspolitiske streng er, at Danmark i højere grad kan og skal tilkoble sig det internationale samfund. Ligesom determinismen er internationalismen en strømning, som blev italesat og promoveret af danske udenrigspolitikere allerede ved det 20. århundredes begyndelse (dengang under begrebet fredspolitik) (Gram-Skjoldager 2012; Pedersen \& Gram-Skjoldager 2015). Selvom der både i de politiske debatter og senere forskningsmæssige diskussioner har været uenighed om, hvorvidt internationalismen var en politisk realistisk og betydningsfuld strategi, har den udgjort et implicit referencepunkt for debatterne om dansk udenrigspolitik efter Den Kolde Krig, hvor begreber som 'aktiv' eller 'aktivistisk internationalisme' har cirkuleret i både politiske og akademiske debatter om udenrigspolitikken (Due-Nielsen \& Petersen 1995; Holm 2002; Pedersen 2012).

Det har været et gennemgående træk i forståelsen af 1900-tallets udenrigspolitiske tradition, at den deterministiske og den internationalistiske strømning er blevet set som modsatrettede, men samtidig indbyrdes forbundne, og som størrelser, der begge med varierende styrke konstant har været til stede i nyere dansk udenrigspolitisk historie. Dette har ledt til, at man oftest beskriver den som dualistisk i spændet mellem disse to grundlæggende ideologier.

\section{Figur 1. En dualistisk udenrigspolitisk tradition}

\section{Dansk udenrigspolitisk tradition}

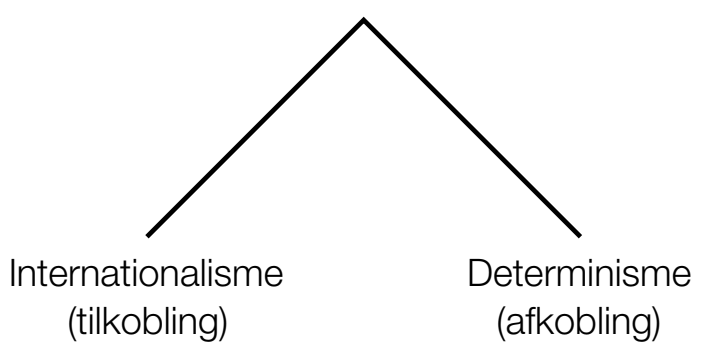

Den følgende analyse søger at analysere udviklingen i den danske udenrigspolitiske tradition gennem et studie af de udenrigspolitiske doktriner, der har styret og guidet dansk udenrigspolitik. Fokus i analysen er, hvordan balancen mellem disse to ideologiske strømninger er kommet til udtryk i de danske doktriner, og hvorvidt man har fastholdt dualismen som overordnet ramme for tolkningen af den danske position internationalt. Empirisk anvendes i det følgende de officielle danske udenrigspolitiske doktriner, som her defineres som "a system of normative and empirical beliefs about the international system and the role of one's own country in that system, as declared 
in public by the official decision-makers of that country" (Brodin 1972, 104). Disse har i studier af dansk udenrigspolitik været fremhævet som en relevant empirisk kilde til at studere staters identitet og perception af det internationale handlerum, de har inden for en given periode (Wivel 2014); jf. desuden Brodin 1972; Neumann \& Heikka 2005). Argumentet er videre, at vi i studiet af disse kan få en mere indgående forståelse af, hvordan småstater tilrettelægger deres tilpasningsstrategier, men også af hvilke mere offensive målsætninger småstater måtte besidde. I det følgende forstås udenrigspolitiske doktriner derfor som et sæt af de grundlæggende principper, som guider en stats udenrigspolitik i en given periode, men de kan sjældent opfattes som konstante, da de oftest reflekterer den internationale og nationale udvikling. De kan således betragtes som generelle vejledninger i forhold til, hvilke mål og midler en stat anvender og anlægger, ligesom de er med til at give et signal til det interne og eksterne publikum om, hvordan 'vi' er, og hvordan et land ser sin placering i den internationale verdensorden (Wivel 2014, 110).

\section{Udvikling i de danske udenrigspolitiske doktriner Udviklingen og konsolideringen af dualisme $i$ dansk udenrigspolitik}

Dansk udenrigspolitik har som nævnt traditionelt været centreret omkring især ét begrebssæt, der relaterer sig til den såkaldte dualistiske tradition. Vigtige eksponenter for den deterministiske tendens i den danske udenrigspolitik er Erik Scavenius og en anden radikal udenrigsminister, P. Munch (1929-1940), der havde en principfast tro på nødvendigheden af, at Danmark, pga. sin position som en lille udsat småstat, tilpassede sig til de internationale magtpolitiske realiteter. Den danske udenrigsminister fra 1929-1940, P. Munch, har betegnet læren af den danske udenrigspolitik siden 1870 , som ,... at det forste og sidste krav vi skal stille til dansk diplomati er, at det skal holde sig i Ro og gøre sit yderste til, at vi kan leve så ubemarket som muligt ..." (Munch citeret i Karup Pedersen 1970, 417). Scavenius har peget på, at „... I realiteten bestemmes Danmarks Udenrigspolitik ved Faktorer, paa hvilke den danske Regering og Rigsdag kun kan øve ringe Indfydelse. Dansk Udenrigspolitiks Hovedopgave bliver derfor at holde sig orienteret om disse Faktorer og deres Samspil og i Forbindelse hermed skønne over det rette ojeblik til at satte ind for at udnytte den til enhver Tid foreliggende Situation til Fremme af Danmarks Interesser ... „(Scavenius 1948, 9). Munchdoktrinen er oftest set som synonym med Scavenius-doktrinen og deler afgjort en række afgørende lighedspunkter ved, at den overordnede sikkerhedstænkning var præget af småstatstankegangen og af ønsket om dansk neutralitet og ikke-indblanding i den internationale magtpolitik. Der er imidlertid også vigtige forskelle mellem de to.
Dette kommer til udtryk ved, at Scavenius-doktrinen i dansk udenrigspolitik bør betragtes som enstrenget deterministisk, da der grundet Danmarks udsatte sikkerhedspolitiske situation ifølge Scavenius ikke var rum for at føre en normbaseret udenrigspolitik. Ligeledes blev det påpeget, at egentlige forsøg på tilkobling via internationalt samarbejde, f.eks. i folkeforbundsregi, blev set som særdeles risikabelt, da man risikerede at komme i situationer, hvor man kunne blive sat i et modsætningsforhold til Tyskland og tvunget til at tage stilling til internationale konflikter, hvor Danmark ikke havde noget væsentligt at vinde (jf. Karup Pedersen 1970; Bjørn \& Due-Nielsen 2003, 466-70; Olesen 2013, 256-60; Lidegaard 2006). Udgangspunktet for Scavenius-tænkningen lå således i komplet dansk afkobling fra det internationale system og den internationale rivalisering mellem de regionale stormagter.

Figur 2. Scavenius-doktrinen - enstrenget determinisme

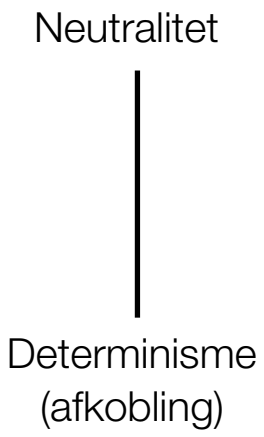

Munchs sikkerhedstænkning delte Scavenius' opfattelse af småstatsudgangspunktet for dansk udenrigspolitik, hvilket betød en erkendelse af, at det var disse magter, der satte rammerne og betingelserne for udøvelsen af den danske udenrigspolitik. Munch-doktrinen åbnede imidlertid for, at småstater trods alt via sin deltagelse i internationalt samarbejde på langt sigt kunne søge at påvirke den internationale ordenspolitik $\mathrm{i}$ en retning, som var mere favorable for småstater ved at arbejde for en højere grad af regulering af den internationale magtpolitik (GramSkjoldager 2012, 67-72; Wivel 2014). Dette åbnede således for den internationalistiske dimension i dansk udenrigspolitik, hvor Danmark via tilkoblingsstrategier kunne søge at fremme og beskytte dansk suverænitet og selvbestemmelse, selvom det overordnede mål fortsat var dansk neutralitet, som vi f.eks. så det i forbindelse med den danske voldgiftspolitik i 1890'erne (Gram-Skjoldager 2012). 
Figur 3. Munchs sikkerhedspolitiske doktrin

- dualistisk udenrigspolitik

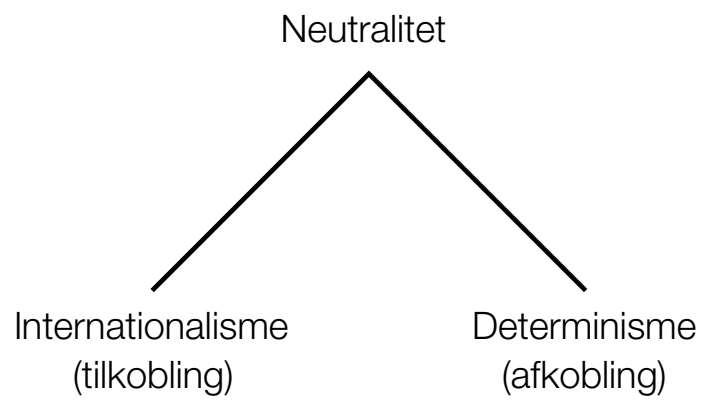

Det er med afsæt i denne dualistiske forståelse blevet et gennemgående træk i forståelsen af 1900-tallets udenrigspolitik, at den deterministiske/tilpasningspolitiske og den internationalistiske strømning er blevet set som modsatrettede, men samtidig indbyrdes forbundne, og som størrelser, der begge med varierende styrke konstant har været til stede i nyere dansk udenrigspolitik. På trods af diskrediteringen af neutralitetspolitikken efter Anden Verdenskrig holdt man i de strategiske miljøer fast i grundforståelsen af den danske udenrigspolitik som dualistisk ved, at man fortsatte med at betone, at Danmark kunne forfølge hhv. tilkoblings- og afkoblingsstrategier. Kragh, og senere Hækkerup, udviklede senere Munchs sikkerhedsforståelse ved, at man præsenterede en relateret opdeling af den danske udenrigspolitik (Olesen \& Villaume 2006). Denne dualisme har således spillet en central rolle i studiet af efterkrigstidens danske udenrigspolitik, hvor den blev udviklet og raffineret via formuleringen af Hækkerups firesøjlemodel (Hækkerup 1965). Denne er oftest også betegnet som den såkaldte kompartmentaliserede udenrigspolitiske strategi (Olesen \& Villaume 2006). Hækkerup udviklede i denne henseende Munchs sikkerhedstænkning ved at identificere forskellige arenaer i den danske udenrigspolitik, hvor hhv. determinisme og internationalisme kunne dominere og koeksistere. Det vil sige, at denne doktrin kodificerede og udbyggede således kombinationen af tilkoblings- og afkoblingsstrategier, som de var udtrykt hos Munch (Scavenius' sikkerhedstænkning var i denne sammenhæng netop ikke dualistisk, men (enstrenget) deterministisk, da afkobling blev set som den primære målsætning for den danske tysklandspolitik). Udgangspunktet herfor var en rationel kalkule af, hvad de danske interesser og præferencer var, og hvilke muligheder man havde for at realisere disse. Disse præferencer blev opdelt i områderne sikkerhed, økonomi og værdipolitik (Wivel 2014). Modellen, som blev formelt kodificeret i 1965, argumenterer for, at den danske udenrigspolitik siden Anden Verdenskrig kunne ses som struktureret omkring fire organisatoriske arenaer med hver deres specifikke funktion for realiseringen af disse interesser. Disse blev opdelt i den atlantiske søjle NATO (sikkerhed), FN (værdier, normer og sikkerhed), EF (økonomi) og det nordiske samarbejde (værdier) (Hækkerup 1965).

Figur 4. Hækkerup-doktrinen - den dualistiske kompartmentaliserede udenrigspolitik

\begin{tabular}{|l|l|}
\hline $\begin{array}{l}\text { EF } \\
\text { (Økonomi) }\end{array}$ & $\begin{array}{l}\text { Nordisk samarbejde } \\
\text { (Idéer) }\end{array}$ \\
\hline FN & NATO \\
(Idéer, normer, sikkerhed) & (Sikkerhed) \\
\hline
\end{tabular}

Denne opdeling var forenelig med den grundlæggende dualistiske spænding, hvor internationalisme og tilkobling aktivt kunne forfølges inden for f.eks. FN-søjlen, mens Danmark kunne føre en mere tilpassende kurs inden for de sikkerhedspolitiske områder eller en mere balancerende linje i det økonomiske samarbejde i EF. Opdelingen betød således en mere kompleks dansk udenrigspolitik, hvor forskellige strategier og interesser kunne dominere i forskellige søjler på forskellige tidspunkter. Derved tjente opdelingen til at sikre og opretholde en dualistisk karakter af Danmarks samlede udenrigspolitiske indsats, hvilket kom til at dominere sikkerhedstænkningen under Den Kolde Krig. Opdelingen betød, at Danmark kunne forfølge en aktiv normpolitik, f.eks. gennem sin bistandspolitik i FN-regi eller i sit arbejde for fred og nedrustning i regi af det nordiske samarbejde, mens man kunne anlægge en mere forsigtig og tilpassende kurs inden for NATO og EF. At der dog ikke altid var udbredt konsensus om tilrettelægningen og vægtningen mellem de forskellige arenaer, kom bl.a. til udtryk i forbindelse med fodnotepolitikken, hvor den danske afkobling i NATO-regi, fremmet af det alternative flertal, ledte til et egentligt brud mellem de politiske fløje. Særligt denne konflikt mellem 1982-1988 kombineret med murens fald var med til at diskreditere den socialdemokratiske doktrin dens grundlæggende dualistiske natur efter Den Kolde Krigs afslutning.

\section{Udviklingen af den enstrengede internationalisme}

I en tale i april 1989 påpegede Uffe Ellemann-Jensen, at denne skarpe opdeling af udenrigspolitikken måtte udfordres og udbygges i forbindelse med Den Kolde Krigs afslutning (Udenrigskommissionen 1990). Han pegede på, at hvis Danmark fortsat skulle operere inden for de fire forskellige søjler, var det vigtigt at etablere en samlet overbygning mellem søjlerne i form af en 'aktiv internationalisme', hvor Danmark på tværs af den organisatoriske opdeling mere aktivt skulle promovere danske 
værdier som demokrati og menneskerettigheder i en international sammenhæng (Udenrigskommissionen 1990; Pedersen 2012; Wivel 2013). Derved blev en af de centrale nyskabelser i 1990 'ernes tidlige aktivistiske udenrigspolitik, at den dualistiske tolkning skulle erstattes af en mere enstrenget udenrigspolitisk strategi (international aktivisme), der skulle tage afsæt i internationalismestrengen (Udenrigskommissionen 1990; Pedersen \& GramSkjoldager 2015). En tendens, der fortsatte og (kuriøst nok) blev implementeret efter regeringsskiftet i 1993, hvor duoen Hans Hækkerup som socialdemokratisk forsvarsminister og den radikale Niels Helveg Petersen som udenrigsminister under de socialdemokratisk ledede regeringer gennem 1990'erne (Pedersen 2012). Denne strategi blev fortsat udtrykt gennem en fælles overligger, der under Nyrup-regeringerne blev betegnet som 'engageret internationalisme', selvom den i hovedtræk delte principperne i den internationale aktivisme (jf. Udenrigsministeriet 1994; 1996).

Sammenlignet med Hækkerup-doktrinen var en primær nyskabelse i denne doktrin, at den opløste den dualistiske karakter i dansk udenrigspolitik og reintroducerede den enstrengede opfattelse af dansk udenrigspolitik, hvor tilkobling og dansk engagement i det internationale samfund blev understreget gennem formuleringen af en bredere tilkoblingsstrategi til internationale organisationer og sikkerhedsalliancer (Udenrigskommissionen 1990). Danmark skulle her udvikle sig til et mainstream-land i EU-sammenhæng, ligesom det skulle blive et kerneland i NATO (Pedersen 2012). Centralt i denne opfattelse af den internationale sikkerhedsstruktur stod således $\mathrm{FN}$, EU og NATO, men sammenlignet med Hækkerupdoktrinen blev deltagelsen heri ikke set som opdelt eller kompartmentaliseret, men som integrerede komponenter $i$ en overordnet mere sammenhængende internationalistisk tilkoblingsstrategi.

Figur 5. Ellemann-Jensen-doktrinen - enstrenget internationalisme

Aktivistisk internationalisme

FN

EU
NATO

\section{Nordisk} samarbejde

Under de liberale regeringer i 00'erne fortsatte denne logik med at dominere i formuleringen af den overordnede officielle strategi (Udenrigsministeriet 2003). Fogh Rasmussen-regeringerne reducerede i deres strategi fokus til tre dimensioner i dansk udenrigspolitik, der blev centreret om det nationale, regionale og globale niveau, som erstattede det eksplicitte fokus på organisationerne i det internationale system. Denne koordinering skulle samles under strategien 'international aktivisme' og skulle forankres i mere eksplicitte værdipolitiske målsætninger, hvor den udenrigspolitiske indsats skulle samles i 'én sammenhængende udenrigspolitik'. ${ }^{1}$ Det påpeges således, at en 'effektiv udenrigspolitik imidlertid forudsatter, at udenrigspolitikkens mange facetter som f.eks. Europa-, udviklings-, sikkerheds-, forsvars-og handelspolitikken integreres, så de er gensidigt forstarkende' (Udenrigsministeriet 2003). Det er således værd at bemærke, at Fogh Rasmussen-doktrinen fortsætter den internationalistiske tendens, der har været i dansk udenrigspolitik efter Den Kolde Krigs afslutning ved, at den fortsætter og konsoliderer tilkoblingsstrategi, men gav internationalismen en ny fortolkning gennem sin insisteren på den atlantiske dimension som forudsætningen for en aktivistisk dansk udenrigspolitik (Pedersen 2012; Wivel 2013). Herved markerede Anders Fogh Rasmussen, at synet på alliancer og alliancemedlemskaber i de permanente sikkerhedsorganisationer ikke længere skulle opfattes som nødvendige platforme for udøvelsen af dansk 'aktivisme', selvom dansk deltagelse og engagement stadig var en prioritet. Denne kunne i stedet praktiseres ved en alternativ tilkobling til international politik ved, at man skulle søge deltagelse i fleksible ad hoc-koalitioner (Udenrigsministeriet 2003). Argumentet var, at dette ville give Danmark et øget internationalt handlerum, forudsat at disse koalitioner havde den nødvendige tyngde og vægt på den internationale scene. Amerikansk lederskab og deltagelse i disse var således set som en nødvendig forudsætning for denne strategis udformning. Anders Fogh Rasmussen pegede senere på, at strategien var møntet på en egentlig transformation af den danske position fra en små- til en mellemstat i det internationale system ved, at man via alliancen med USA fik et øget internationalt handlerum (Rasmussen 2006). Det øgede handlerum og reduktionen i vægten på de permanente sikkerhedspolitiske arenaer i dansk udenrigspolitik kan illustreres i figur 6, hvor den enstrengede forståelse af dansk udenrigspolitik præsenteres under overskriften international aktivisme, som netop i modsætning til den aktivistiske internationalisme betoner det øgede danske handlerum til at manøvrere uden om de permanente alliancestrukturer på forskellige internationale arenaer. Netop understregningen af, at Danmark skulle agere på forskellige niveauer i det internationale system, påpegede ambitionen om, at Danmark skulle til at manøvre som en 'mellemstat' snarere end en småstat (Rasmussen 2006).

Figur 6. Fogh Rasmussen-doktrinen - enstrenget international tilkobling

International aktivisme

\begin{tabular}{l|l|l}
\hline Globalt & Atlantisk & Regionalt
\end{tabular}


Efter Anders Fogh Rasmussens udtræden af den danske politiske scene forsvandt en del af den indenrigspolitiske drivkraft bag denne doktrin og dens sikkerhedstænkning. Udenrigsministeriet lagde i deres debatpapir fra 2009 op til en revision af den danske udenrigspolitiske strategi, hvor internationale organisationer igen fik en mere fremtrædende plads som følge af den øgede internationale magtspredning. Udgangspunktet for denne strategi og den senere tænkning, som er kommet til udtryk under Thorning-regeringerne, har således på doktrinbasis prioriteret den danske aktivisme internationalt via de permanente alliancestrukturer, hvilket således har ledt til, at Knudsen har peget på, at perioden efter Fogh Rasmussen har en række lighedstræk med 1990'ernes aktivistiske internationalisme, f.eks. i forhold til deltagelsen i operationerne i Syrien, Mali og Libyen (Knudsen 2014).

\section{Udvikling og tendenser $i$ de danske udenrigspoli- tiske doktriner}

Ovennævnte analyse har peget på en relativ klar udviklingstendens i den danske udenrigspolitiske strategi. Denne er gået fra en enstrenget neutralitetspolitik over en dualistisk position til en enstrenget internationalistisk strategi, som i forskellige former har domineret i perioden efter Den Kolde Krigs afslutning. Argumentet er således, at vi har været vidne til en stigende tendens til en bredere dansk tilkoblingsstrategi til det internationale system, hvilket har ledt til, at internationalisme er blevet den centrale komponent i den danske udenrigspolitik, som har betydet en (periodevis) afsked med den dualistiske kerne i den danske strategiske kultur. Den enstrengede strategi, der blev indført efter Den Kolde Krigs afslutning i den såkaldte Ellemann-Jensen-doktrin, har således - ligesom Hækkerup-doktrinen før den - vist sig relativ langtidsholdbar i den danske udenrigspolitik. Der har i den politiske og akademiske debat været en tendens til at betegne denne udvikling som aktivisme i dansk udenrigspolitik. Begrebsmæssigt er dette uheldigt, da begrebssætningen er vanskelig at sætte ind i en bredere dansk udenrigspolitisk historisk tradition, der traditionelt ellers har kredset om determinisme og internationalisme. Aktivisme siger i sig selv ikke noget om typen af den udenrigspolitiske ideologi, der fremmes, da man som under Scavenius så, at man sagtens kunne forfølge en aktiv tilpasning til Tyskland. I tolkningen her i artiklen er aktivismen ikke noget særegent for perioden efter Den Kolde Krigs afslutning, men beskriver i stedet forskellige tilkoblingsstrategier indordnet under internationalismen. En første fase beskrevet via doktrinen om internationalistisk aktivisme, som understreger dansk tilkobling gennem internationale organisationer og disses ageren på den internationale scene. Desuden er det argumentet, at vi kan identificere en anden fase i denne internationalistiske bølge, som på doktrinniveauet beskriver en dansk tilkobling uden om permanente alliancestrukturer gennem et mere snævert samarbejde i fleksible ad hoc-koalitioner (jf. Udenrigskommissionen 1990; Udenrigsministeriet 2003). En adfærd, der på en række områder bryder med den traditionelle danske strategiske kulturtænkning og dens afsæt i småstatsforståelsen. Fogh Rasmussen-doktrinen tager således afsæt i forestillingen om et øget dansk handlerum, hvor Danmark i stedet kan agere som en mellemstat i det internationale system.

Overordnet set har denne udvikling og tyngdeforskydning fra enstrenget determinisme til enstrenget internationalisme været muliggjort af de ændringer, vi har været vidne til i det internationale system. Her tænkes ikke mindst på bevægelsen væk fra et polært regionalt system i mellemkrigsårene over et konkurrencebetonet bipolært system under Den Kolde Krig til et unipolært amerikansk ledet system efter Den Kolde Krigs afslutning. I perioder med svage kapabiliteter, aggressive regionale nabolande og et konfrontatorisk bipolart system (19451989) har dette betydet en tilbagetrukket tilpassende udenrigspolitik. ${ }^{2}$ Arven fra særligt P. Munchs dualistiske doktrin med tilkoblings- og afkoblingselementer forblev et centralt element i den danske udenrigspolitiske strategi under Den Kolde Krig og har sat sit præg på den danske allianceadfærd inden for f.eks. NATO-samarbejdet, hvor det danske medlemskab blev betegnet som tøvende og ikke fuldt engageret (jf. Villaume 1995; se desuden Hækkerup 1965, 9-10). Det danske engagement i EF var ligeledes i perioden fra 1972 til 1986 præget af en skeptisk blokerende rolle over for institutionelle forandringer af samarbejdet (Pedersen 2013; Petersen 2006a), ${ }^{3}$ mens vi på den anden side fulgte en normbaseret og værdipræget kurs i nordisk regi og via bistandspolitikken i FN.

Traditionelt har forklaringer af den danske udenrigspolitik således lagt sig på linje med en realistisk inspireret fortolkning, hvor særligt trusler og andre staters muligheder for kapabilitetsprojektering til dansk territorium har været set som den primære forklarende variabel (Waltz 1979). Inden for den såkaldte adaptionsteoretiske tradition har forklaringen af den danske udenrigspolitik traditionelt været betragtet som en kombination af indenrigspolitiske og udenrigspolitiske faktorer, hvor f.eks. stresssensitivitet og Danmarks relative kapabilitetskapacitet ses som determinerende for typen af dansk tilpasning, givet kombinationen af værdier på de to dimensioner (Petersen 1977; 2000). Dette har traditionelt betydet, at man i studiet af dansk udenrigspolitik har påpeget eksistensen af et begrænset handlerum, hvorfor betydningen af indenrigspolitiske faktorer i mindre grad har været anset som de mest relevante forklaringsfakto- 
rer (Petersen 2006b). I litteraturen har der imidlertid i stigende grad i takt med internationalismens indtog efter Den Kolde Krigs afslutning og det deraf forøgede danske handlerum været en gryende interesse i at afsøge de indenrigspolitiske faktorers betydning. Argumentet har været, at eksterne faktorer nok kan betragtes som nødvendige, men ikke tilstrækkelige faktorer til at forklare de specifikke udenrigspolitiske valg i den brede nye tilkoblingsstrategi, der har karakteriseret perioden. Dette skyldes, at det øgede handlerum har medført og muliggjort en række ændringer i den danske tilkoblingsstrategi, som har varieret over øget fokus på internationale organisationer, ordenspolitik og deltagelse i fredsbevarende operationer til egentlig krigsførelse og deltagelse i ad hoc-koalitioner og ambitionen om øget selvstændighed i den danske udenrigspolitik. Der har været diskussion om Fogh Rasmussen-doktrinen, som med sin snævre alliance med USA er blevet udlagt som ekstrem tilpasning eller ekstrem atlantisme (Mouritzen 2007), om hvorvidt perioden betegner et brud eller en bredere kontinuitet med tidligere tiders deterministiske tendens. Artiklen her har imidlertid peget på, at der kan findes et kontinuitetselement i Fogh Rasmussen-doktrinen, som rækker tilbage til den enstrengede internationalistiske streng, som blev introduceret af Uffe Ellemann-Jensen og implementeret under de socialdemokratiske regeringer i 1990'erne. Derved lægger artiklen sig på linje med en række analyser, som peger på en ny traditionsbrydende dansk udenrigspolitik efter Den Kolde Krigs afslutning (jf. Heurlin 1993; Holm 1998; 2002; Petersen 2006a). Især Nikolaj Petersen har efterfølgende udbygget sin analyse af internationalismens indtog og peget på et aktivistisk skifte i den danske udenrigspolitik, som knytter sig til afslutningen af Den Kolde Krig. Årsagen til skiftet kan dog tidsfæstes tidligere (Petersen 2009). Argumentet er, at kimen til skiftet kan findes i et ønske hos særligt Venstre og i mindre grad det Konservative Folkeparti om et opgør med den dominerende socialdemokratisk-radikale position i udenrigspolitik igennem 1980'erne samt med venstrefløjens generelle håndtering af de udenrigspolitiske spørgsmål under Den Kolde Krig (Petersen 2009). Denne tolkning peger på etableringen af et egentligt paradigmeskifte i udenrigspolitikken, hvor daværende udenrigsminister Uffe Ellemann-Jensen allerede før Den Kolde Krigs afslutning optrådte som drivkraften hen imod en internationalistisk dansk udenrigspolitik.

\section{Konklusion}

Sondringen mellem den dualistiske tostrengede og den senere enstrengede opfattelse er af afgørende betydning, når man analytisk vil forstå variationen $\mathrm{i}$ udviklingen $\mathrm{i}$ dansk udenrigspolitik, herunder også i forhold til spørgs- målet om, hvordan man vurderer brud og kontinuitetstræk i den danske udenrigspolitik. Tolkningsdebatterne i litteraturen er med andre ord komplekse og ikke helt nemme at tegne et samlet billede af, fordi analyserne af dansk udenrigspolitik og herunder også forklaringen af den variation, der kan observeres i mere eller mindre eksplicit grad, kredser om enten brud- eller kontinuitetsfortolkninger, men oftest er relativt vage om deres analytiske udgangspunkt i forhold til enten determinisme/ tilpasning, internationalisme eller den samlede dualistiske tradition i dansk udenrigspolitik. Et yderligere lag af kompleksitet opstår i den forbindelse, fordi der i debatten om den danske udenrigspolitik efter Den Kolde Krig og især VK-regeringernes udenrigspolitik samtidig er blevet introduceret et nyt analytisk begreb, nemlig aktivismebegrebet. ${ }^{4}$ I modsætning til tilpasningsbegrebet, der fremstår teoretisk veludviklet og velkonsolideret $\mathrm{i}$ analyserne af dansk udenrigspolitik, er aktivismebegrebet imidlertid konceptuelt svagere udviklet, og det varierer, hvordan forskellige forskere relaterer det til tidligere udenrigspolitikformer. ${ }^{5}$ Litteraturen har dog generelt implicit associeret aktivismen med internationalismen i dansk udenrigspolitik grundet dens erklærede ambition om at integrere og øge det danske internationale engagement enten via deltagelsen i internationale organisationer eller via bilaterale relationer med f.eks. USA, dvs. en stærk vægt på tilkobling som udenrigspolitisk strategi. Analytikere, der har beskæftiget sig med spørgsmålet om tilpasning og aktivisme, har således oftest kredset om diskussioner af Fogh Rasmussen-perioden ud fra en diskussion af brud eller kontinuitet. Dette har som regel haft karakter af en diskussion af, hvorvidt der er tale om enten tilpasning eller aktivisme i den valgte kurs over for USA i forbindelse med deltagelsen i de to koalitionskrige i perioden. Derved bunder disse analyser mere eller mindre eksplicit $i$ en antagelse om eksistensen af en enstrenget snarere end en dualistisk udenrigspolitik.

Den del af litteraturen, der overvejende har beskæftiget sig med analyser af dansk udenrigspolitik som tostrenget, har modsat analytikere, der opererer med en enstrenget forståelse, oftest haft vanskeligere ved at håndtere brud og kontinuitet, da man som regel har fokuseret på tyngdeforskydninger mellem de to ideologier eller netop understreget kontinuiteten inden for de forskellige arenaer i dansk udenrigspolitik. Der er således i dette perspektiv sjældent tale om åbne brud i forhold til den danske udenrigspolitiske tradition, da de valgte strategier vil være betoninger af forskellige grundlæggende udviklingstræk i denne, ligesom vægten i den udenrigspolitiske strategi kan skifte fra en arena til en anden. Disse tolkninger har for det meste haft en vægt på eksterne faktorers betydning og har med dette afsæt oftest søgt at 
argumentere for kontinuitet med reference til de eksterne faktorers relevans og betydning.

Der er imidlertid noget, der taler for, at den mere offensive variant af aktivismen, som blev praktiseret under Fogh Rasmussen, begrebsmæssigt ligger ud over indholdet i de to grundlæggende ideologier. I denne tolkning er perioden åbenlyst ovre i den internationalistiske ideologi, men spørgsmålet er, om aktiv krigsdeltagelse og høj international synlighed er forenelige med tilkoblingsbegrebet og den grundlæggende småstatstanke, der ligger bag den dualistiske fortolkningsramme. I dette perspektiv bliver spørgsmålet om brud og kontinuitet med den grundlæggende danske udenrigspolitiske tradition også relevant, da perioden derved potentielt repræsenterer et grundlæggende brud med denne underlæggende forståelse af dansk udenrigs- og sikkerhedspolitik, selvom den dog fortsat kan tolkes inden for rammerne af den enstrengede danske udenrigspolitiske tradition.

En af konsekvenserne af det øgede handlerum som følge af reduktionen i det eksterne pres har været et stadigt stigende fokus på nationale faktorer, når vi har søgt at forklare typen af dansk tilkobling, da Danmark har fået flere handlemåder, og en større frihed til at vælge typen af reaktion og typen af tilkobling. Dette medfører, at indenrigspolitiske determinanter i stigende grad er blevet centrale i forklaringen af dansk udenrigspolitik, ikke mindst i betoningen af hvilken type af aktiv tilkoblingsstrategi Danmark har valgt. I denne bølge af litteratur har tendensen generelt været, at man har peget på, at tyngdepunktet for idéudvikling og doktrintænkning er flyttet væk fra Socialdemokratiet og de radikale og over til den danske højrefløj, hvor det har været fremhævet, at særligt partiet Venstre og dets politiske ledere har spillet en central og afgørende rolle i doktrinudviklingen i perioden.

\section{Litteraturliste}

Bjøl, E 1970, 'P. Munch, sociologisk og historisk set', Historie, bd. IX, hf. 2, pp. 123-41.

Bjøl E 1996, 'Foreign Policy-Making in Denmark', Cooperation and Conflict, pp. 1-17.

Bjørn, C \& C Due-Nielsen 2003, Fra helstat til nationalstat. Dansk Udenrigspolitiks Historie 1814-1914, Danmarks Nationalleksikon, bind 3, Gyldendal, København.

Branner, H 2000, 'The Danish Foreign Policy Tradition and the European Context', pp. 185-220 in H Branner \& M Kelstrup (red.), Denmarks Policy towards Europe after 1945. History Theory and Options, Odense Universitetsbibliotek, Odense.

Branner, H 2013, 'Denmark between Venus and Mars: How Great a Change in Danish Foreign Policy?', pp. 134-66 in N Hvidt \& H Mouritzen (red.), Danish Foreign Policy Yearbook 2013, Danish Institute for International Studies, Copenhagen.
Brodin, K 1972, 'Belief Systems, Doctrines, and Foreign Policy: A Presentation of Two Alternative Models for the Analysis of Foreign Policy Decision-Making', Cooperation and Conflict, vol. 7, no. 1, pp. 97-112.

Due-Nielsen, C \& N Petersen 1995 (red.), Adaptation \& Activism: The Foreign Policy of Denmark 1967-1993, DUPI/DJØF, København.

Gram-Skjoldager, K 2012, Fred og Folkeret: dansk internationalistisk udenrigspolitik 1899-1939. Museum Tusculanum, København.

Heurlin, B 1993, 'Nye prioriteringer i dansk udenrigspolitik', pp. 30-50 in Dansk Udenrigspolitisk Årbog 1993, Dansk Institut for Internationale Studier, København.

Holbraad, C 1991, Danish Neutrality. A Study in the Foreign Policy of a Small State, Clarendon Press, Oxford.

Holm, HH 1998, 'Denmark's Active Internationalism: Advocating International Norms with Domestic Constraints', pp. 52-80 in B Heurlin \& H Mouritzen (red.), Danish Foreign Policy Yearbook 1997, DUPI, København.

Holm, HH 2002, 'Danish Foreign Policy Activism: The Rise and Decline', pp. 19-45 in B Heurlin \& H Mouritzen (red.), Danish Foreign Policy Yearbook 2002, DUPI, Copenhagen.

Hækkerup, P 1965, Danmarks Udenrigspolitik, AOF Fremad, Århus.

Karup Pedersen, O 1970, Udenrigsminister P. Munchs opfattelse af Danmarks stilling $i$ international politik, Københavns Universitets Institut for Samtidshistorie og Statskundskab skrifter 2, GEC Gads Forlag, København.

Knudsen, TB 2014, 'Danish Contributions in Syria and Mali: Active Internationalism in a Changing World Order', pp. 76-108 in N Hvidt \& H Mouritzen (red.), Danish Foreign Policy Yearbook 2014, DIIS, Copenhagen.

Lidegaard, B 2006, Overleveren 1914-1945, Dansk Udenrigspolitiks Historie, Danmarks Nationalleksikon, bind 4, Gyldendal, København.

Mouritzen, H 2007, 'Denmarks Super Atlanticism', Journal of Transatlantic Studies, vol. 5, no. 2, pp. 155-67.

Neumann, IB \& H Heikka 2005, 'Grand Strategy, Strategic Culture Practice: The Social Roots of Nordic Defence', Cooperation and Conflict, vol. 40, no. 1, pp. 5-23.

Olesen, MR 2013, In the Eye of the Decision-Maker, University of Copenhagen, Copenhagen.

Olesen, TB \& P Villaume 2006, I blokopdelingens tegn, Dansk Udenrigspolitiks Historie, Danmarks Nationalleksikon, bind 5, Gyldendal, København.

Pedersen, RB 2012, 'Danish Foreign Policy Activism: A Case of Differences of Degree?', Cooperation and Conflict, vol. 47, no. 3, pp. 331-49.

Pedersen, RB 2013, “Footnote Policy' and the Social Democratic Party's Role in Shaping Danish EEC Positions, 1982-1986', Scandinavian Journal of History, vol. 38, no. 5, pp. 636-57.

Pedersen, RB \& K Gram-Skjoldager 2015, 'International aktivisme i dansk udenrigspolitik 2001-2009. En tværfaglig forskningsstatus', Historisk tidsskrift, nr. 2.

Petersen, N 1977, 'Adaption as a Framework for Foreign Policy Analysis', Cooperation and Conflict, vol. 28, pp. 373-402.

Petersen, N 1999, 'Bjøl og studiet af dansk udenrigspolitik', pp.11-20 in H Pundik (red.), Bjøl. Et festskrift til Erling Bjøl, Aarhus Universitetsforlag, Aarhus.

Petersen, N 2000, 'National Strategies in the Integration Dilemma: The Promises of Adaptation Theory', pp. 72-99 in H Branner \& M Kelstrup (red.), Denmarks Policy towards Europe after 1945. History, Theory and Options, Odense Universitetsforlag, Odense.

Petersen, N 2006a, Europaisk og globalt engagement 1973-2006, Dansk Udenrigspolitiks Historie, Danmarks Nationalleksikon, bind 6, Gyldendal, København. 
Petersen, N 2006b, 'Handlerummet for dansk udenrigspolitik efter Muhammed-krisen', Den nye verden - Tidsskrift for internationale studier, nr. 2, pp. 31-60.

Petersen, N 2009, 'Kampen om Den Kolde Krig i dansk politik og forskning', Historisk Tidsskrift, årg. 109, nr. 1, pp. 154-204.

Rasmussen, AF 2006, 'Danmark må gøre op med småstatsmentaliteten', Ugebrevet Mandag Morgen, 11.9.2006.

Rasmussen, MV 2005, 'What's the Use of It?: Danish Strategic Culture and the Utility of Armed Forces, Cooperation and Conflict, vol. 40, no. 1 , pp. 67-89.

Rynning, S 2003, 'Denmark as a Strategic Actor? Danish Security Policy after 11. September', pp. 23-46 in Danish Foreign Policy Yearbook 2003, Danish Institute For International Studies, København.

Scavenius, E 1948, Forhandlingspolitikken under besettelsen, Steen Hasselbalchs Forlag, København.

Skidmore, D 1994, 'Explaining States Responses to International Change: The Structural Sources of Foreign Policy Rigidity and Change', pp. 50-56 in JA Rosati, JD Hagan \& MW Sampson III (red.), Foreign Policy Restructuring: How Governments Respond to Global Change, University of South Carolina Press, Columbia.

Snyder, J 1991, Myth of Empire: Domestic Politics and International Ambition, Cornell University Press, Ithaca, NY.

Udenrigskommissionen 1990, Udenrigstjenesten mod år 2000, Betankning nr. 1209, Udenrigskommissionen af 1. April 1989, Udenrigsministeriet, København.

Udenrigsministeriet 1994, Principper og perspektiver i dansk udenrigspolitik. Dansk udenrigspolitik på vej mod år 2000, Udenrigsministeriet, København.

Udenrigsministeriet 1996, Strategier for en multilateral indsats, Udenrigsministeriet/Danida, København.

Udenrigsministeriet 2003, En verden i forandring. Regeringens bud på nye prioriteter i Danmarks Udenrigspolitik, Regeringen, København.

Villaume, P 1995, 'Allieret med Forbehold-Danmark, NATO og Den Kolde Krig: en studie i dansk sikkerhedspolitik 1949-1961', Vandkunsten - konflikt, politik \& historie, nr. 11/12, april.
Waltz, K 1979, The Theory of International Politics Reading, AddisonWesley, MA.

Wivel, A 2013, 'From Peacemaker to Warmonger? Explaining Denmark's Great Power Politics', Swiss Political Science Review, vol. 19, no. 3, pp. 298-321.

Wivel, A 2014, 'Still Living in the Shadow of 1864? Danish Foreign Policy Doctrines and the Origins of Denmark's Pragmatic Activism', pp. 109-39 in N Hvidt \& H Mouritzen (red.), Danish Foreign Policy Yearbook 2014, DIIS, Copenhagen.

\section{Noter}

1. Hvorvidt koldkrigsårenes funktionelle kompartmentalisering af udenrigspolitikken faktisk blev udbygget og overskredet efter Den Kolde Krig og ikke mindst under Fogh Rasmussen, er et væsentligt spørgsmål, som forskningen i VK-regeringernes udenrigspolitik også - ofte implicit eller ubevidst - forholder sig til.

2. Neutralitetstraditionen har gennem tiderne haft forskellige former og indhold. Holbraad (1991) har peget på en række forskellige grader af neutralismen, som har udfoldet sig i perioden fra $1720 \mathrm{og}$ frem til afslutningen af Den Kolde Krig. Den dominerende perception i den nyere debat om den danske neutralitetspolitik har kredset om det, som Holbraad definerer som 'isoleret', 'forsvarsløs' og 'latent' neutralitet (Holbraad 1991).

3. Småstatsrollen ledte endvidere Socialdemokratiet og venstrefløjen ind i en aktiv kamp for pacifisme og ønsket om at etablere en atomvåbenfri zone i Norden. Dette ønske førte desuden til en række stærke reservationer over for deployeringen af NATO-styrker på dansk territorium.

4. For analyser af aktivismebegrebet se f.eks. Holm (2002); Knudsen (2014); Mouritzen (2007); Pedersen (2012); Rynning (2003); Wivel (2013); Pedersen \& Gram-Skjoldager (2015).

5. Se f.eks. Pedersen (2012) og Wivel (2013) for en oversigt over brugen af aktivismebegrebet i dansk udenrigspolitik. 